Мірзасва М. С., аспірант*

Полтавська державна аграрна академія

\title{
ОКРЕМІ МОРФОЛОГІЧНІ, МІКРОБІОЛОГІЧНІ, БІОХІМІЧНІ ПОКАЗНИКИ РОТОВОЇ ТА КРЕВІКУЛЯРНОЇ РІДИН У КЛІНІЧНО ЗДОРОВИХ СОБАК
}

\section{Рецензенти - доктор ветеринарних наук А. А. Замазій, доктор медичних наук, професор К. С. Непорада}

\begin{abstract}
У роботі представлені результати лабораторних досліджень ротової та кревікулярної рідин у клінічно здорових собак (морфологічний склад, мікробіологічні та біохімічні показники). На основі проведених комплексних досліджень зазначених вище субстратів визначено: кількість та видовий ландшафт мікроорганізмів, з'ясовано клітинний склад (відсоток: десквамованого плаского епітелію, лейкочитів - лімфоциити, нейтрофіли та слинних тілець), біохімічні показники: активність аспартатамінотрансферази, аланінаміно-трансферази, лужної фосфатази, лізоциму, а також встановлено вміст загального білка, холестеролу, загального кальиію, електролітів (натрію, калію, хлору) та $\mathrm{pH}$.
\end{abstract}

Ключові слова: собака, ротова рідина, кревікулярна рідина, клітинний та мікробіологічний склад, біохімічні показники.

Постановка проблеми. Серед безлічі профілактичних заходів першорядним завданням гігієни $\epsilon$ правильний догляд за ротовою порожниною. Виявляється, справа це не така вже й легка, як може здатися на перший погляд. Відомо, що на патогенез запальних процесів у пародонті та на перебіг запальної реакції в ньому впливає мікрофлора ротової порожнини і вплив окремих факторів неспецифічного захисту. На сучасному етапі розвитку ветеринарної стоматології $є$ лише незначна кількість фундаментальних досліджень, присвячених вивченню хвороб пародонту, в яких автори з'ясували роль мікрофлори ротової порожнини в патогенезі запальних процесів у пародонті та вплив окремих факторів неспецифічного захисту на перебіг запальної реакції $[1,3,6,16]$.

Аналіз основних досліджень і публікацій, у яких започатковано розв'язання проблеми. У гуманній стоматології зустрічаються повідомлення про доцільність проведення досліджень із метою з'ясування динаміки клітинного складу, біохімічних та імунологічних показників, а та- кож мікробіологічних - кревікулярної та ротової рідин для підвищення лікувальної ефективності запальних процесів у пародонті $[4,14]$.

Однак слід зазначити, що запозичення отриманих даних зі стоматології гуманної медицини $\epsilon$ наразі некоректним. Тому виникає нагальна потреба дослідити зазначені показники у клінічно здорових та хворих на пародонтопатії собак, оскільки за допомогою поглибленого вивчення цих показників у ротовій та кревікулярній рідинах можна вчасно провести ранню діагностику захворювання та патогенетично обгрунтувати план лікування.

Мета дослідження: обгрунтувати доцільність дослідження ротової та кревікулярної рідин у клінічно здорових собак.

Завдання дослідження: з'ясувати низку морфологічних мікробіологічних, а також біохімічних показників ротової та кревікулярної рідин у клінічно здорових собак.

Матеріали і методи. Дослідження були проведені на базі кафедри хірургії та акушерства ПДАА. У п'ятьох клінічно здорових (на момент дослідження) безпородних собак 1-1,5-річного віку масою 15-20 кг за десятиденного контролю показників тріасу відбирали ротову та кревікулярну рідини з метою виявлення окремих морфологічних, мікробіологічних та біохімічних показників.

Відбір ротової та кревікулярної рідин проводили вранці натщесерце. Зразки ротової рідини для мікробіологічних, морфологічних, біохімічних досліджень отримували наступним чином: рідину відбирали у стерильну пробірку за допомогою 2 мл шприца системи «Люера» без голки. Перед цим осушували оточуючі тканини стерильними марлевими тампонами. У лабораторії дослідний матеріал вносили на поживні середовища жовтково-сольовий агар, агар Ендо, агар Сабуро та 5 \% кров'яний агар [9].

* Науковий керівник-кандидат ветеринарних наук С. М. Кулинич 


\section{СТОРІНКА МОЛОДОГО ВЧЕНОГО}

Підрахунок кількості колоній утворюючих одиниць проводили методом секторних посівів за Gould [12]. Видову ідентифікацію мікроорганізмів здійснювали згідно з визначником Берджі [7].

Дослідження морфологічного складу ротової рідини проводили двома методами: для підрахунку загальної кількості клітин - відібрану ротову рідину поміщали в розчин Тюрка у співвідношенні 20:1, після чого перемішували. Отриманим розчином заповнювали камеру Горяєва. Загальну кількість клітинних елементів підраховували в 100 великих квадратах [4, 10].

Для встановлення складу компонентів ротової рідини, диференціації десквамованого плаского епітелію, слинних тілець, лімфоцитів та нейтрофілів краплю відібраної ротової рідини фіксували на предметному склі - фарбували за Романовським-Гімзою. У подальшому підраховували їх відсоток однопольним методом [11].

Проби кревікулярної рідини для мікробіологічних та морфологічних досліджень отримували за методиками Ериной С. В., Дьячковой С. Я., а також Жулева Е. Н., Серова А. Б. [5, 8], адаптованої нами шляхом взяття зразків 3 ясенного жолобка 3 апроксимальних поверхонь зубів за допомогою стерильних ендодонтичних паперових штифтів ISO 30 (Meta Biomed, United Kindom) попередньо осушуючи оточуючі тканини стерильними марлевими тампонами, 10 штифтів вводили до дна жолобка й залишали там на 5 хвилин. Далі для мікробіологічних досліджень зразки переносили у стерильну пробірку з транспортним середовищем і суміш доставляли у лабораторію, а для морфологічних досліджень штифти переносили у пробірку з 200 мкл фізіологічного розчину натрію хлориду, залишали на 30 хв для вимивання ії компонентів, після чого штифти виймали і впродовж двох годин проводилися дослідження (для уникнення руйнування матеріалу).

Досліджуючи морфологічний склад кревікулярної рідини, встановлювали загальну кількість клітин та їх відсоткове співвідношення. Для встановлення загальної кількості ясенну рідину, розведену в розчині $\mathrm{NaCl}$, поміщали в розчин Тюрка у співвідношенні 10:1, після чого перемішували й вносили в камеру Горяєва. Клітинні елементи підраховували по всій площі сітки камери [10]. Для 3'ясування видового складу клітин - десквамованого плаского епітелію, а також лейкоцитів (лімфоцити, нейтрофіли) - краплю ясенної рідини вносили у фізіологічний розчин натрію хлориду, фіксували на склі та фарбували методом Романовського-Гімзи. Підраховували кількість клітинних елементів по всій площі предметного скла, а далі диференціювали форми лейкоцитів [2, 8]. Визначення інтенсивності виділення ясенної рідини здійснювали методом [15].

Біохімічні дослідження ротової рідини проводилися за такими показниками: АсАТ, АлАТ, ЛФ, а також встановлено вміст загального білка, холестеролу, загального кальцію, електролітів (натрію, калію, хлору) та рН. Для цього застосовували напівавтоматичний біохімічний аналізатор ВА 88, Mindray (КНДР).

Визначення лізоцимної активності ротової рідини проводили фотоелектроколориметричним (КФК-3) методом у модифікації відділу зоогігієни УНДІЕВ, а як тест-культуру використовували M. Lisodeicticus (штам 2655) [13].

Отриманий експериментальний матеріал опрацьовували методом варіаційної статистики з визначенням середніх арифметичних (М) та стандартних відхилень (m).

Результати досліджень. У результаті проведених лабораторних досліджень із відібраних зразків ротової рідини нами було отримано ріст мікроорганізмів на поживних середовищах із родів Staphylococcus (S. epidermidis), Acinetobacter (A. calcoaceticus), Klebsiella (K. oxytoca), Esherichia (E. colli).

Нами встановлено, що на жовтково-сольовому агарі реєстрували ріст S. epidermidis у вигляді гладких білуватих випуклих колоній.

На Ендо ідентифіковано бактерії видів A. calcoaceticus, K. oxytoca, E. colli. Перший вид проростав у вигляді слизових рожевих колоній із рівними краями, у діаметрі мали 2,5 мм. Вид $\mathrm{K}$. oxytoca проростав на поживному середовищі у вигляді округлих рожевих слизових колоній iз рівними краями від 0,5 до 2 мм (табл. 1), а вид E. colli був діагностований на підставі формування червоних колоній округлої форми 3 рівними краями 3 характерним металевим блиском розмір добових колоній становив 2 міліметри.

Зазначені види мікроорганізмів давали ріст i на $5 \%$ кров'яному агарі. Так, вид S. epidermidis на кров'яному агарі проростав у вигляді білих колоній із рівними краями, що мали правильну круглу форму; вид А. calcoaceticus проростав у вигляді дрібних непрозорих білуватих колоній, круглих, із рівними краями. У процесі росту $\mathrm{K}$. oxytoca відмічали ріст сірих слизових округлих колоній розміром 3 мм у діаметрі, a E. colliокруглі, сірі колоніі, 2 мм у діаметрі.

Підраховуючи їх кількість в 1 мл рідини отримали наступні результати: S. epidermidis $-10^{6}$ KУO, A. calcoaceticus $-10^{5}$, K. oxytoca $-5 \times 10^{4}$, а також E. colli $-5 \times 10^{3}$ КУО (див. рис.). 


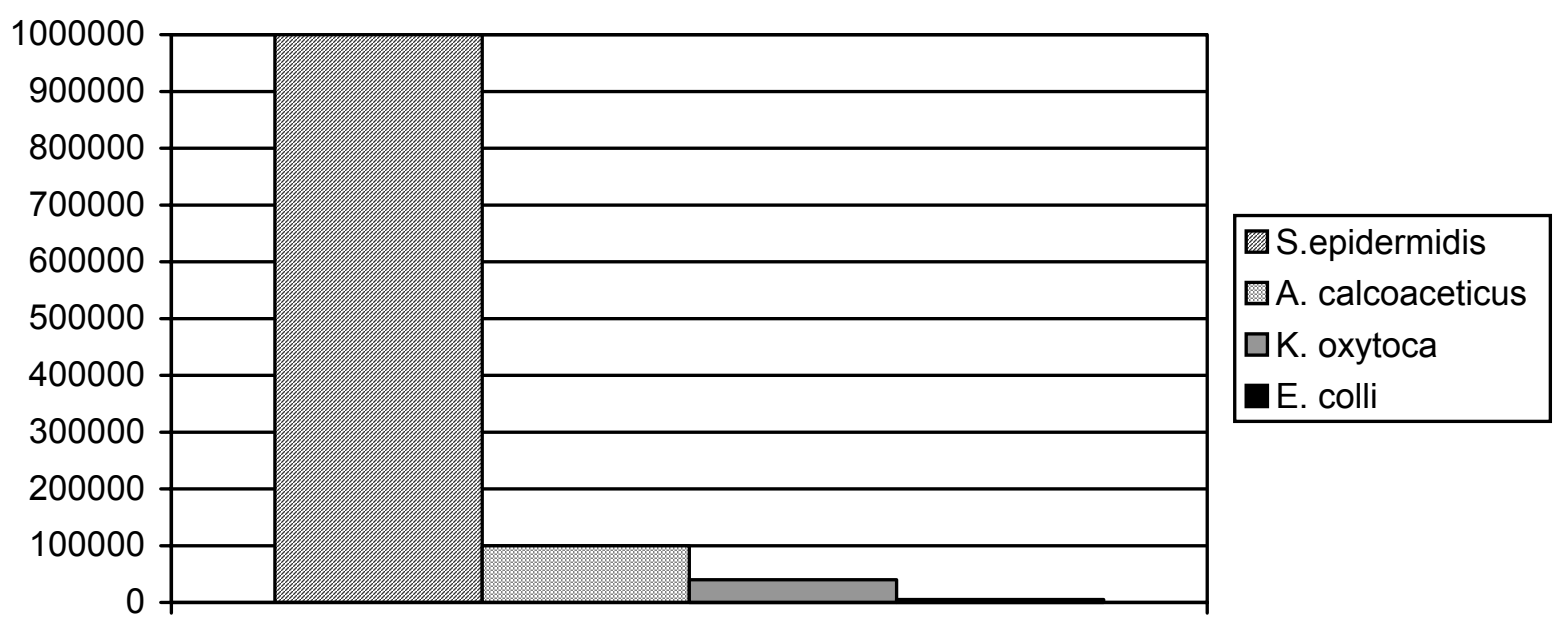

\section{Рис. Кількість колонісутворюючих одиниць, отриманих зі зразків ротової рідини}

1. Склад мікроорганізмів, виділених зі зразків ротової рідини, за культивування на живильних середовищах $(n=5)$

\begin{tabular}{|c|c|c|c|c|}
\hline \multirow{2}{*}{$\begin{array}{c}\text { Види } \\
\text { мікроорганізмів }\end{array}$} & \multicolumn{4}{|c|}{ Середовища } \\
\cline { 2 - 5 } & жовтково-сольовий агар & Ендо & Сабуро & 5 \% кров'яний агар \\
\hline S. epidermidis & + & - & - & + \\
\hline A. calcoaceticus & - & + & - & + \\
\hline K. oxytoca & - & + & - & + \\
\hline E. colli & - & + & - & + \\
\hline
\end{tabular}

У процесі висіву зразків кревікулярної рідини від здорових особин отримали на поживному середовищі Ендо ріст бактерій виду Е. colli - $10^{4}$ КУО.

Аналізуючи отримані результати проведених досліджень (кількісну характеристику та видову ідентифікацію мікроорганізмів), можемо констатувати наступне: мікробіологічний склад ротової та кревікулярної рідин не одноманітний. Так, за результатами дослідження виділено чотири види мікроорганізмів у ротовій рідині та один у ясенній і встановлено, що вони відносяться до групи умовно-патогенних.

Підраховуючи формені елементи ротової рідини у камері Горяєва нами встановлено, що у клінічно здорових тварин загальна кількість лейкоцитів



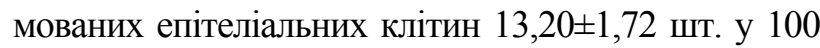
великих квадратах. Відповідно, в кревікулярній рі-

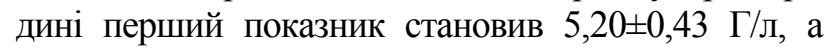
другий $-6,80 \pm 0,86$ шт. у 100 великих квадратах. У процесі підрахунку формених елементів у фарбованих мазках, отриманих із ротової рідини, встановили, що відсоток десквамованого плаского епітелію був на рівні $53,20 \pm 3,86$; слинних ті-

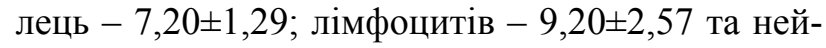

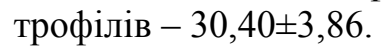

\section{2. Біохімічний склад ротової рідини} в клінічно здорових собак (M士m)

\begin{tabular}{|c|c|}
\hline Показник & Тварини $\mathrm{n}=5$ \\
\hline АсАТ, од./л & $31,80 \pm 4,29$ \\
\hline АлАТ, од./л & $20,40 \pm 4,29$ \\
\hline ЛФ, од./л & $55,40 \pm 13,73$ \\
\hline Лізоцим, \% & $10,05 \pm 1,79$ \\
\hline pH & $7,63 \pm 0,14$ \\
\hline Загальний білок, г/л & $0,19 \pm 0,12$ \\
\hline Холестерол, ммоль/л & $0,26 \pm 0,06$ \\
\hline Натрій, ммоль/л & $81,78 \pm 2,23$ \\
\hline Калій, ммоль/л & $16,98 \pm 0,43$ \\
\hline Кальцій, ммоль/л & $2,62 \pm 0,20$ \\
\hline Хлор, ммоль/л & $46,54 \pm 3,37$ \\
\hline
\end{tabular}

У мазках, виготовлених із кревікулярної рідини, не вдавалося нараховувати 100 клітин: середні показники кількості плаского епітелію ста-


нейтрофілів - $12,40 \pm 2,14 \%$.

На етапі встановлення інтенсивності виділення ясенної рідини встановлено, що ії показники у здорових тварин становили $4,20 \pm 0,21$ мг за 5 хвилин. 


\section{СТОРІНКА МОЛОДОГО ВЧЕНОГО}

Окрім того, згідно з поставленими завданнями, ми проводили біохімічні дослідження зразків ротової рідини від здорових тварин. Результати досліджень представлені в таблиці 2.

Висновки: 1. У процесі проведення лабораторних досліджень ротової та кревікулярної рідин у клінічно здорових собак визначено: кількість, видовий склад мікроорганізмів, з'ясовано клітинний склад (відсоток: десквамованого плаского епітелію, лейкоцитів - лімфоцити, нейтрофіли та слинних тілець), біохімічні показники:

\section{БІБЛІОГРАФІЯ}

1. Арушанян А. Г. Кариозно-пульпитные поражения зубов у собак // Ветеринарная патология. 2010. - №3. - 19 c.

2. Борисов Л. Б. Микробиология и иммунология стоматологических заболеваний / Л. Б. Борисов, И. С. Фрейдлин // В кн.: Медицинская микробиология, вирусология, иммунология / Под ред. Л. Б. Борисова, А. И. Смирновой. - М. : Медицина, 1994. - С. 496-522.

3. Васильева М. Б. Воспалительные заболевания пародонта у собак: автореф. дис. ... канд. вет. наук. / М. Б. Васильева. - Санкт-Петербург, 2009. - 21 c.

4. Деркач Л.3., Пюрик В.П., Пантус А.В. [mа ін.]. Зміни клітинного складу ясенної рідини у хворих на генералізований пародонтит та методи їх корекції у комплексному лікуванні захворювань пародонту // Галицький лікарський вісник. Т.16. - 2009. - №4. - С. 1-4.

5. Ерина С. В., Дьячкова С. Я. Цитологическое исследование десневой жидкости при заболеваниях пародонта // Лабораторное дело. - 1989. №6. - C. 14-15.

6. Ільницький М. Г., Арсеєнко Д. В. Поширеність хвороб пародонту у собак // Вісник Білоцерків. держ. аграр. ун-ту. - Вип. 41. - Біла Церква, 2006. - С. 55-61.

7. Определитель бактерий Берджи / Под ред. Хоулта Дж., Крича Н., Смита П.И. [и др.]. В двух томах. - М. : Медицина, 1982.

8. Пат. 2349920 RU MПК (2007) G01N33/68, А61В10/00 Способ исследования десенной жидкости. Пат. 2349920 RU MПК (2007) G01N33/68, А61В10/00; Е. Н. Жулев, А. Б. Серов; Федеральная служба по интеллектуальной собственности, патентам и товарным знакам. Заявл. 2007120235/15 от 30.05.2007; Опубл. 20.03.2009; Бюл. № $54 .-3$ c. активність АсАТ, АлАТ, ЛФ, лізоциму, а також встановлено вміст загального білка, холестеролу, загального кальцію, електролітів (натрію, калію, хлору) та $\mathrm{pH}$.

2. У перспективі використання зазначених вище показників у хірургічній практиці дасть змогу більш інформативно діагностувати, раціонально та патогенетично обгрунтовано проводити раннє лікування й профілактувати низку інших захворювань ротової порожнини у собак.

9. Приказ МинЗдрава СССР № 535 от 22.04.1985 «Об унификации микробиологических (бактериологических) методов исследования, применяемых в клинико-диагностических лабораториях лечебно-профилактических учреждений». C. $18-28$.

10. Ронин В. С., Старобинец Г. М., Утевский Н. Л. Руководство к практическим занятиям по методам клинических лабораторных исследований // В. С. Ронин, Г. М. Старобинец, Н. Л. Утевский. М. : Медицина, 1989. - 318 с.

11. Султанов М. Г., Жубантаев И. Н., Дискешев А. К. Лабораторные исследования крови у различных животных / Методические указания. - Уральск, 2006. $-40 \mathrm{c}$

12. Фельдман Ю. М. Количественное определение бактерий в клинических материалах // Лаб. дело. 1984. - №10. - С. 616-619.

13. Чумаченко В. Е., Сичкарь В. С., Оленич Ю. В. Методические рекомендации по определению естественной резистентности у сельськохозяйственных животных для ветеринарних специалистов. - К.: УСХА, 1992. -46 с.

14. Яночкина Н. С. Комплексное применение магнитно-лазерной терапии и дентальной адгезивной пасты солкосерила для профилактики и лечения хронического рецидивирующего афтозного стоматита: автореф. дис. ... канд. мед. наук. / Н. С. Яночкина. - М., 2006. - C. 8-21.

15. http://intranet.tdmu.edu.ua/data/kafedra/internal/ stomat_ter/classes_stud/ФПО/Інтерни/Загальний $\%$ 20розділ/1.\%20р.н/Профілактика\%20стоматологічних $\% 20$ захворювань/оцінка\%20гігієнічного\% 20 стану\%20порожнини\%20рота\%20\%20i\%20 тканин\%20пародонту..htm

16. Lobpris H. B. Small animal dentistry / H. B. Lobpris. - Blackwell publishing, 2007. -414 p. 